Jurnal Ilmu Ilmu Agribisnis: Journal of Agribusiness Science, 9(1), Februari 2021

\title{
PENDAPATAN DAN KESEJAHTERAAN RUMAH TANGGA PETANI PADI PENGOLAH IKAN ASAP DAN NON PENGOLAH IKAN ASAP (KASUS DI DESA KEBON DAMAR, KECAMATAN MATARAM BARU, KABUPATEN LAMPUNG TIMUR)
}

\author{
(Household Income and Welfare of Smoked Fish Processing Rice Farmers and Nonsmoked Fish Processing \\ (Case in Kebon Damar Village, Mataram Baru Subdistrict, East Lampung Regency))
}

Susanto, Yaktiworo Indriani, Maya Riantini

Jurusan Agribisnis, Fakultas Pertanian, Universitas Lampung, J1. Prof. Dr. Soemantri Brojonegoro No. 1 Bandar Lampung 35145, e-mail: yaktiworo.indriani@fp.unila.ac.id

\begin{abstract}
This research aims to calculate the income and welfare of rice farmers who processsmoked fish and who do not process. The research was carried out in Kebon Damar Village from July to August 2019 using a survey method. The determination of the sample was done in stage (multistage sampling). The sample in this research amounted to 57 rice farmers. The data were analyzed using income analysis, $R$ - $C$ ratio, and household welfare according to the 1997 Sajogyo's criteria. The results showed that the largest contribution of household income of nonsmoked fish processing ricefarmers came from rice farming or 71.45 percent of the total household income. Whereas, the largest contribution of household income of smoked fish processing rice farmers came from the smoked fish processing business or 54.43 percent of the total household income. Smoked fish processing rice farmers weremore prosperous than nonsmoked fish processing rice farmers.
\end{abstract}

Keywords: Household income, household welfare, rice farmers, smoked fish.

\section{PENDAHULUAN}

Provinsi Lampung merupakan salah satu provinsi di Indonesia yang mayoritas perekonomiannya bertumpu pada sektor pertanian. Pada tahun 2017, sektor pertanian di Provinsi Lampung memberikan kontribusi sebesar 30,40 persen dari total produk domestik regional bruto (PDRB). Kemampuan sektor pertanian untuk memberikan kontribusi secara langsung terhadap pertumbuhan ekonomi dan kesejahteraan rumah tangga (RT) petani tergantung pada tingkat pendapatan usahatani dan surplus yang dihasilkan. Pendapatan usahatani merupakan salah satu faktor utama penentu kesejahteraan RT petani dan sebagai salah satu faktor penting dalam mengkondisikan ekonomi RT (Suratiyah 2009).

Rendahnya tingkat kesejahteraan ciri dari tingkat kemiskinan penduduk di suatu wilayah. Masalah kemiskinan identik dengan keterbatasan dalam kepemilikan dan penguasaan sumberdaya fisik dan nonfisik oleh RT petani. Lampung merupakan provinsi di Indonesia dengan persentase jumlah penduduk miskin yang cukup tinggi. Berdasarkan BPS (2018), persentase penduduk miskin menurut provinsi di Indonesia (2007-2018), Provinsi Lampung tergolong kedalam provinsi dengan jumlah penduduk miskin ke-10 dengan persentase sebesar 13,14 persen.

Kabupaten Lampung Timur merupakan salah satu kabupaten yang ada di Provinsi Lampung dengan jumlah penduduk miskin cukup besar yaitu 167.64 ribu jiwa pada tahun 2017 (BPS 2019). Tingkat pendapatan RT merupakan indikator penting untuk mengetahui tingkat hidup RT. Ketidakmampuan RT dalam memenuhi kebutuhan makanan dan bukan makanan ditinjau dari sisi pengeluaran merupakan salah satu indikator yang digunakan untuk mengukur kemiskinan dengan konsep kemampuan memenuhi kebutuhan dasar (basic need approach).

Salah satu subsektor pertanian yang berperan penting bagi perekonomian dan pendapatan RT adalah subsektor tanaman pangan. Komoditas tanaman pangan yang memberikan peranan penting bagi perekonomian di Indonesia salah satunya adalah tanaman padi. Padi menjadi komoditas tanaman pangan unggulan di Indonesia. Hal ini mengacu pada besarnya luas panen dan produksi padi yang selalu menempati posisi pertama (Kementerian Pertanian 2019).

Provinsi Lampung merupakan provinsi ke tujuh dengan tingkat produksi padi terbesar di Indonesia 
pada tahun 2018 yaitu sebesar 4.556 .378 ton. Kabupaten Lampung Timur merupakan kabupaten dengan tingkat produksi padi terbesar kedua di Provinsi Lampung dan merupakan sumber pendapatan RT berusahatani padi bagi petani. Produksi padi di Kabupaten Lampung Timur mengalami peningkatan dari 645.913 ton pada tahun 2016 meningkat menjadi 667.730 ton pada tahun 2017.

Kecamatan Mataram Baru merupakan salah satu kecamatan yang terletak di Lampung Timur yang terdiri dari tujuh desa yang seluruhnya melakukan kegiatan usahatani padi dan menjadikan usahatani padi sebagai salah satu mata pencaharian utama walaupun produksinya bukan merupakan yang tertinggi di Kabupaten Lampung Timur. Desa Kebon Damar merupakan desa dengan jumlah luas panen terkecil kedua di Kecamatan Mataram Baru yaitu hanya sebesar 91 ha. Jumlah luas panen padi di Desa Kebon Damar yang relatif sempit, hal ini perlu dilakukan kajian lebih lanjut apakah dengan jumlah luas lahan panen padi yang sempit dapat memberikan kontribusi pendapatan petani, sehingga dapat menyejahterakan rumah tangga.

Berdasarkan hasil penelitian yang dilakukan oleh Putri dan Noor (2018) menunjukkan semakin luas kepemilikan lahan, semakin besar kontribusi pendapatan sektor pertanian terhadap pendapatan total RT petani. Untuk dapat meningkatkan pendapatan RT nya, petani perlu melakukan usaha lain di luar bidang pertanian untuk mendapatkan sumbangan pendapatan lain, sehingga pendapatan RT dapat meningkat dan berdampak pada kesejahteraan RT.

Beberapa petani padi di Desa Kebon Damar dengan jumlah luas panen yang sempit memanfaatkan kekayaan sumberdaya laut Kabupaten Lampung Timur. Kabupaten Lampung Timur memiliki jumlah produksi perikanan tangkap terbesar di Provinsi Lampung yang dapat dimanfaatkan oleh masyarakat untuk melakukan usaha pengolahan ikan asap dengan tujuan untuk memperoleh kontribusi pendapatan lain, agar kebutuhan pangan dan nonpangan dapat terpenuhi. Jenis ikan yang digunakan sebagai bahan baku pengolahan ikan asap adalah ikan pari dan ikan cucut. Jenis ikan pari dan ikan cucut merupakan jenis komoditas ikan yang tidak memiliki nilai jual untuk dipasarkan dan termasuk ke dalam kategori jenis ikan rucah. Melihat keadaan tersebut, beberapa RT petani padi di Desa Kebon Damar melakukan pengolahan ikan asap dengan tujuan untuk mendapat keuntungan dari hasil pengolahan ikan asap tersebut.

Desa Kebon Damar merupakan sentra produksi usaha ikan asap di Kecamatan Mataram Baru. meskipun Desa Kebon Damar bukan merupakan daerah pesisir sebagai penghasil ikan asap, sehingga mengharuskan petani pengolah ikan asap harus membeli bahan baku ikan pari dan cucut segar di desa lain untuk diolah menjadi ikan asap. Selama ini, RT petani pengolah maupun nonpengolah ikan asap belum melakukan perhitungan pendapatan secara total terkait dengan usaha yang mereka lakukan baik dalam usahatani padi maupun pengolahan ikan asap. Berdasarkan keadaan tersebut, perlu dianalisis untuk mengetahui kontribusi pendapatan RT termasuk kontribusi dari pengolahan ikan asap saja serta tingkat tingkat kesejahteraan RT petani padi pengolah dan nonpengolah ikan asap.

\section{METODE PENELITIAN}

Penelitian ini dilakukan di Desa Kebon Damar, Kecamatan Mataram Baru, Kabupaten Lampung Timur. Penentuan lokasi penelitian dilakukan secara purposive dengan pertimbangan bahwa penduduk Desa Kebon Damar sebagian besar bekerja sebagai petani padi dengan luas lahan panen paling sempit ke dua di Kecamatan Mataram Baru serta sebagai sentra produksi ikan asap di Kecamatan Mataram Baru, Kabupaten Lampung Timur, meskipun desa tersebut bukan merupakan penghasil bahan baku ikan laut segar jenis pari dan cucut untuk diolah menjadi ikan asap. Sumber bahan baku berupa ikan pari dan cucut berasal dari Desa Kuala Penet yang masyarakatnya bekerja sebaga nelayan di pantai.

Penelitian ini dilakukan menggunakan metode survei. Metode survei adalah penelitian dengan melakukan penyelidikan untuk memperoleh faktafakta dari gejala yang adadan mencari keterangan faktual baik tentang institusi sosial, ekonomi, atau politik dari suatu kelompok atau daerah tertentu yang dilakukan dengan pengamatan langsung dalam populasi besar atau kecil menggunakan kuesioner yang berisi daftar pertanyaan untuk mengumpulkan data (Sugiarto 2003).

Penentuan sampel dalam penelitian ini menggunakan metode multistage sampling yaitu penentuan sampel secara bertahap. Mula-mula diambil sampel blok kemudian baru diambil 
sampel petani (Suparmoko 1999). Populasi dalam penelitian ini berjumlah 523 RT petani yang berasal dari 18 kelompok tani. Setelah diketahui jumlah populasinya maka ditentukan sampel penelitian dengan metode multistage sampling. Sampel blok dalam penelitian adalah sampel blok jarak lokasi sawah terdekat dengan saluran irigasi (kelompok tani Sidomuncul 2) dan sampel blok lokasi sawah dengan jarak terjauh dari saluran irigasi (kelompok tani Harapan Makmur 2).

Jumlah sampel setiap kelompok tani yang dipilih ditentukan menggunakan metode sensus, karena jumlah populasi kelompok tani terpilih kurang dari 30 responden. Jumlah sampel kelompok tani Sidomuncul 2 berjumlah 23 petani dan kelompok tani Harapan Makmur 2 berjumlah 19 petani, sehingga didapatkan total seluruh sampel petani padi nonpengolah ikan asap sebanyak 42 petani responden, sedangkan jumlah sampel petani padi pengolah ikan asap di luar dari kelompok tani Sidomuncul 2 dan Harapan Makmur 2 sebanyak 15 RT petani. Total seluruh sampel yang digunakan dalam penelitian sebanyak 57 RT petani.

Jenis data yang digunakan dalam penelitian ini adalah data primer berupa data produksi usahatani padi petani pengolah dan nonpengolah ikan asap Desa Kebon Damar, produksi usaha pengolahan ikan asap, serta data pengeluaran kebutuhan pangan dan nonpangan RT. Data sekunder berupa data produksi padi di Kabupaten Lampung Timur, jumlah produksi perikanan tangkap Provinsi Lampung, gambaran umum Kabupaten Lampung Timur dan profil Desa Kebon Damar.

Data primer diperoleh secara langsung dari observasi dan pengamatan serta pencatatan secara langsung di lapangan dengan menggunakan kuesioner atau angket (daftar pertanyaan) yang telah disiapkan sebelumnya. Data sekunder diperoleh dari studi literatur dan pustaka di dinas dan instansi terkait dengan penelitian. Cara pengumpulan data dalam penelitian ini dilakukan dengan cara wawancara langsung kepada responden dengan menggunakan angket atau kuesioner penelitian yang sudahdisiapkan. Pengumpulan data dilakukan pada bulan Juli sampai Agustus 2019.

Metode analisis data yang digunakan dalam penelitian ini adalah analisis deskriptif kuantitatif dan analisis kuantitatif. Analisis deskriptif kualitatif digunakan untuk menggambarkan objek penelitian yaitu tingkat kesejahteraan RT petani padi. Analisis kuantitatif digunakan dalam penelitian ini untuk mengetahui besarnya pendapatan RT petani padi di Desa Kebon Damar, Kecamatan Mataram Baru, Kabupaten Lampung Timur.

Pendapatan RT petani diperoleh dengan cara menjumlahkan seluruh pendapatan yang berasal dari usahatani padi (on farm), non usahatani padi (off farm), dan pendapatan usaha di luar pertanian (non farm). Untuk mengetahui pendapatan RT petani digunakan rumus Rahim dan Hastuti (2008).

$\mathrm{Prt}=\mathrm{P}$ on farm $+\mathrm{P}$ off farm $+\mathrm{P}$ non farm.

Keterangan:

Prt = Pendapatan rumah tangga $(\mathrm{Rp})$

$\mathrm{P}$ on farm = Pendapatan usaha nonpadi (Rp)

$\mathrm{P}$ off farm = Pendapatan luar usahatani (Rp)

$\mathrm{P}$ non farm $\quad=$ Pendapatan non pertanian $(\mathrm{Rp})$

Analisis data untuk menjawab tujuan kesejahteraan RT petani padi pengolah dan nonpengolah ikan asap yaitu dengan menggunakan analisis kuantitatif dengan menggunakan indikator Sajogyo (1997). Pengeluaran RT per kapita per tahun adalah total pengeluaran RT petani baik pengeluaran untuk pangan maupun non pangandalam setahun dibagi jumlah tanggungan RT, selanjutnya dikonversikan ke dalam ukuran setara beras per kilogram, agar dapat diketahui tingkat kemiskinannya.

Tingkat pengeluaran per kapita per tahun pada RT petani dan tingkat pengeluaran per kapita per tahun setara beras dapat dirumuskan Sajogyo (1997) sebagai berikut:

C/kapita/tahun (Rp)

$$
\begin{aligned}
& =\frac{\mathrm{C}}{\sum \text { Keluarga }} \ldots \ldots . . .(2) \\
& =\frac{\frac{\mathrm{C}}{\text { Kapita }} / \text { tahun }}{\text { Harga beras }} \ldots . . . .(3)
\end{aligned}
$$

Klasifikasi kemiskinan menurut Sajogyo (1997) digolongkan kedalam enam bagian yaitu sebagai berikut :
a. $\quad$ Paling miskin $=$ jika pengeluaran per anggota keluarga adalah $180 \mathrm{~kg}$ setara beras per tahun.
b. Miskin sekali $=$ jika pengeluaran per anggota keluarga $180-240 \mathrm{~kg}$ setara beras per tahun.
c. Miskin $=$ jika pengeluaran per anggota keluarga adalah 240-320 kg setara beras per tahun.
d. Nyaris miskin = jika pengeluaran per anggota keluarga 320-480 kg setara beras per tahun. 
e. $\quad$ Nyaris miskin $=$ jika pengeluaran per anggota keluarga adalah 320-480 kg setara beras per tahun.

f. Cukup = jika pengeluaran per anggota keluarga adalah 480-960 kg setara beras per tahun.

g. $\quad$ Hidup layak $=$ jika pengeluaran per anggota keluarga adalah $>960 \mathrm{~kg}$ setara beras per tahun.

\section{HASIL DAN PEMBAHASAN}

\section{Karakteristik Responden}

Rata-rata umur petani responden petani padi pengolah ikan asap dan non pengolah ikan asap secara berturut turut berkisar antara 27-60 tahun dan 27-62 tahun. Berdasarkan indikator BPS 2018, kelompok umur petani responden di daerah penelitian tergolong ke dalam usia produktif, karena semua usia responden lebih dari 15 tahun. Tingkat pendidikan petani padi pengolah dan non pengolah ikan asap secara berturut turut mayoritas menyelesaikan tingkat pendidikan Sekolah Dasar (SD) yaitu sebesar 80,00 persen dan 69,05 persen.

Rata-rata RT keluarga responden memiliki jumlah tanggungan anggota keluarga antara 2-3 orang dengan persentase tanggungan keluarga petani padi pengolah ikan asap sebesar 80,00 persen dan tanggungan keluarga petani padi nonpengolah ikan asap sebesar 80,95 persen. Rata-rata lama pengalaman berusahatani padi petani pengolah dan nonpengolah ikan asap di lokasi penelitian berkisar antara 14-20 tahun. Pengalaman berusaha ikan asap rata-rata berkisar antara 8-15 tahun. Luas lahan petani padi pengolah dan nonpengolah ikan asap berturut-turut sebesar 0,48 ha dan 0,66 ha.

\section{Pendapatan Usahatani Padi}

Pendapatan usahatani padi yang diperoleh RT petani padi pengolah dan nonpengolah ikan asap dalam luasan lahan 0,48 ha dan 0,66 ha berturutturut sebesar Rp15.517.616,54 dan Rp24.828.211,70 per tahun, sedangkan jika dikonversikan dalam satuan per hektar, maka tidak terjadi banyak perbedaan pendapatan antara petani padi pengolah ikan asap maupun petani padi nonpengolah ikan asap yaitu berturut-turut sebesar Rp44.837.500,00 per tahun dan Rp48.914.399,10 per tahun. Biaya terbesar yang dikeluarkan oleh petani padi pengolah dan nonpengolah ikan asap adalah biaya sewa lahan dan tenaga kerja luar keluarga. $\mathrm{R} / \mathrm{C}$ rasio atas biaya tunai pada musim tanam satu (MT 1) yang diperoleh petani padi pengolah dan nonpengolah ikan asap dari kegiatan usahatani padi berturut-turut sebesar 3,85 dan 4,61, untuk MT 2 berturut-turut sebesar 3,33 dan 2,02.

Pendapatan usahatani padi di Desa Kebon Damar, Kecamatan Mataram Baru, Kabupaten Lampung Timur tidak sejalan dengan penelitian yang dilakukan oleh Sugesti, Abidin, dan Kalsum (2015). Pendapatan usahatani padi di Kecamatan Bumi Ratu Nuban, Kabupaten Lampung Tengah lebih rendah yaitu sebesar Rp21.233.663 per 0,78 ha per tahun dengan penguasaan lahan lebih luas. Keadaan ini dikarenakan biaya yang dikeluarkan oleh petani padi di Desa Bumi Ratu Nuban lebih besar jika dibandingkan dengan pengeluaran biaya oleh petani padi di Desa Kebon Damar.

Hasil produksi usahatani padi sejalan dengan penelitian yang dilakukan oleh Mardliyah dan Ainul (2018) tentang risiko produksi usahatani padi di Kabupaten Lampung Timur. Rata-rata produksi usahatani padi di Kabupaten Lampung Timur dengan luas lahan rata-rata yang dikuasai oleh petani relatif sempit yaitu hanya sebesar 0,46 ha dan 0,48 ha berturut-turut mampu menghasilkan produksi padi sebesar $2.459,25 \mathrm{~kg}$ dan $3.021,42 \mathrm{~kg}$ dalam satu kali musim tanam dengan kondisi iklim dan karakteristik pertanian yang hampir sama dengan keadaan iklim di daerah penelitian.

\section{Pendapatan Usaha Pengolahan Ikan Asap}

Periode produksi yang dilakukan oleh RT petani padi pengolahan ikan asap beragam yaitu beberapa RT petani melakukan produksi setiap hari, empat kali produksi dalam satu minggu dan lima kali produksi dalam satu minggu dengan rata-rata produksi ikan asap pari dan cucut berturut-turut sebesar $114 \mathrm{~kg} / \mathrm{bulan}$ dan $99 \mathrm{~kg} / \mathrm{bulan}$. Pendapatan bersih RT petani padi pengolah ikan asap rata-rata sebesar Rp1.827.093,92 per bulan atau Rp21.397.126,98 per tahun.

Pendapatan pengolahan ikan asap yang dihasilkan oleh RT petani padi pengolah ikan asap di Desa Kebon Damar lebih rendah dibandingkan dengan pendapatan pengolahan ikan salai patin di Desa Penyawasan, Kecamatan Kampar yang diteliti oleh Ramli, Anggraini, dan Intan (2012). Pendapatan yang dihasilkan dari pengolahan ikan salai Patin di Desa Penyawasan sebesar Rp2.072.200,00 per bulan. Hal ini dikarenakan kapasitas produksi dan harga di Desa Penyawasan lebih besar yaitu $500 \mathrm{~kg}$ dengan hasil bersih $150 \mathrm{~kg}$ per satu kali produksi dijual dengan harga Rp50.000,00/kg. 


\section{Pendapatan Nonpadi (On Farm)}

Pendapatan total dari kegiatan usahatani nonpadi petani pengolah ikan asap adalah sebesar Rp1.760.000,00 per tahun dan pendapatan usahatani nonpadi petani nonpengolah ikan asap sebesar Rp5.128.571,43 per tahun. Pendapatan nonpadi diperoleh dari kegiatan ternak bebek, ternak kambing, ternak sapi, kolam, usahatani karet dan usahatani jagung.

\section{Pendapatan di Luar Usahatani Padi (Off Farm)}

Pendapatan total petani responden dari kegiatan off farm petani padi pengolah ikan asap yaitu sebesar Rp21.397.126,98 per tahun yang berasal dari usaha pengolahan ikan asap, sedangkan pendapatan off farm yang diperoleh RT petani nonpengolah ikan asap sebesar Rp1.309.523,81 per tahun. Sumber pendapatan off farm petani padi pengolah ikan asap hanya dari pengolahan ikan asap saja disebabkan tidak adanya tenaga kerja lagi yang dapat dicurahkan untuk melakukan usaha lain (off farm), karena proses pengolahan ikan asap membutuhkan waktu pengolahan yang lama.

\section{Pendapatan Usaha Nonpertanian (Nonfarm)}

Rata-rata pendapatan total dari usaha nonpertanian (nonfarm) yang diperoleh petani padi pengolah ikan asap dan nonpengolah ikan asap berturut-turut sebesar Rp640.000,00 per tahun dan Rp3.482.857,14 per tahun. Pendapatan nonfarm diperoleh dari kegiatan usaha warung kecil, warung sembako, mencari di alam bebas, buruh nonpertanian, karyawan toko, karyawan bengkel, warung pecel dan sopir.

\section{Pendapatan Rumah Tangga}

Pendapatan RT merupakan total pendapatan yang diterima oleh RT petani baik yang berasal dari pendapatan kepala keluarga maupun pendapatan dari anggota keluarga, seperti istri dan anak. Sumber pendapatan RT petani responden berasal dari kegiatan usahatani (on farm) baik usahatani padi maupun non padi, kegiatan di luar usahatani (off farm) dan kegiatan nonpertanian (nonfarm).

Tingkat pendapatan RT akan berpengaruh terhadap tingkat kesejahteraan RT petani. Semakin tinggi tingkat pendapatan RT petani, maka akan semakin tinggi juga tingkat kesejahteraan RT, karena pemenuhan baik untuk kebutuhan pangan maupun nonpangan RT dapat tercukupi. Rata-rata pendapatan RT petani padi pengolah dan nonpengolah ikan asap di Desa Kebon Damar, Kecamatan Mataram Baru, Kabupaten Lampung Timur dapat dilihat pada Tabel 1.

Rata-rata pendapatan RT petani padi pengolah ikan asap sebesar Rp39.059.440,74 per tahun. Kontribusi pendapatan RT terbesar berasal dari pendapatan usaha diluar usahatani yaitu usaha pengolahan ikan asap sebesar Rp21.397.126,98 atau 54,78 persen.

Dari data pada Tabel 1, dapat menjelaskan bahwa usaha pengolahan ikan asap merupakan sumber pendapatan RT yang paling penting untuk memenuhi kebutuhan baik pangan maupun non pangan RT. Rata-rata pendapatan RT petani padi nonpengolah ikan asap sebesar Rp34.471.658,52 per tahun dengan kontribusi pendapatan RT terbesar berasal dari pendapatan usahatani padi yaitu sebesar Rp24.550.706,14 atau 71,22 persen.

\section{Pengeluaran Rumah Tangga}

Proporsi pengeluaran RT petani padi pengolah ikan asap menunjukkan pengeluaran nonpangan RT lebih besar daripada pengeluaran pangan RT. Proporsi pengeluaran RT petani padi pengolah ikan asap lebih besar untuk pengeluaran nonpangan

Tabel 1. Rata-rata pendapatan rumah tangga per tahun petani padi pengolah dan nonpengolah ikan asap, 2019

\begin{tabular}{|c|c|c|c|c|}
\hline & \multicolumn{2}{|c|}{ Petani Padi Pengolah Ikan Asap } & \multicolumn{2}{|c|}{ Petani Padi Nonpengolah Ikan Asap } \\
\hline Sumber Pendapatan RT & Pendapatan (Rp) & Persentase (\%) & Pendapatan (Rp) & Persentase (\%) \\
\hline $\begin{array}{l}\text { Pendapatan dari usahatani } \\
\text { padi (on farm) MT1 + MT2 }\end{array}$ & $15.517 .616,54$ & 39,47 & $24.828 .211,70$ & 71,45 \\
\hline $\begin{array}{l}\text { Pendapatan usahatani non } \\
\text { padi (on farm) }\end{array}$ & $1.760 .000,00$ & 4,48 & $5.128 .571,43$ & 14,76 \\
\hline $\begin{array}{l}\text { Pendapatan di luar usahatani } \\
\text { (off farm) }\end{array}$ & $21.397 .126,98$ & 54,43 & $1.309 .523,81$ & 3,77 \\
\hline $\begin{array}{l}\text { Pendapatan dari usaha non } \\
\text { pertanian (non farm) }\end{array}$ & $640.000,00$ & 1,63 & $3.482 .857,14$ & 10,02 \\
\hline Jumlah & $39.0314 .743,52$ & 100,00 & $34.749 .164,08$ & 100,00 \\
\hline
\end{tabular}


yaitu sebesar 51,33 persen dari total pengeluaran sebesar Rp27.105.600,00, sedangkan pengeluaran RT petani padi nonpengolah ikan asap lebih besar untuk pengeluaran kebutuhan pangan sebesar 55,71 persen dari total pengeluaran RT. Berdasarkan proporsi pengeluaran RT, dapat diketahui petani padi pengolah ikan asap lebih sejahtera dibandingkan dengan petani padi nonpengolah ikan asap, karena alokasi pengeluaran RT petani padi lebih besar untuk memenuhi kebutuhan nonpangan daripada untuk kebutuhan pangan RT. Data pengeluaran RT petani padi pengolah dan nonpengolah ikan asap di Desa Kebon Damar, Kecamatan Mataram Baru, Kabupaten Lampung Timur dapat dilihat pada Tabel 2. Data pada Tabel 2 dapat diketahui bahwa pengeluaran pangan terbesar RT petani padi pengolah dan nonpengolah ikan asap terbesar untuk pengeluaran pangan pokok berturut-turut sebesar 26,41 persen dan 23,86 persen diikuti dengan pengeluaran untuk rokok berturut-turut sebesar 16,67 persen dan 16,15 persen lebih besar daripada pengeluaran RT untuk kebutuhan pangan nabati dan pangan hewani.

Data pada Tabel 2 juga menunjukkan persentase pengeluaran nonpangan RT petani padi pengolah dan nonpengolah ikan asap paling besar untuk pengeluaran bahan bakar di luar untuk kebutuhan pengolahan ikan asap berturut-turut sebesar 21,30 persen dan 22,55 persen kemudian diikuti pengeluaran untuk kebutuhan sosial berturut-turut sebesar 15,81 persen dan 21,37 persen. Kondisi ini sejalan dengan penelitian yang dilakukan Hernanda, Indriani dan Kalsum (2017) tentang pendapatan dan ketahanan pangan RT petani padi ladang di desa rawan pangan yang memberikan hasil bahwa pengeluaran total rata-rata RT petanipadi sawah di Desa Sukamarga untuk pengeluaran kebutuhan pangan dan nonpangan relatif seimbang atau sama yaitu sebesar 52,48 persen dan 47,52 persen.

Tabel 2. Pengeluaran rumah tangga per tahun petani padi pengolah dan nonpengolah ikan asap di Desa Kebon Damar

\begin{tabular}{|c|c|c|}
\hline Jenis Pengeluaran & $\begin{array}{l}\text { Petani Padi Pengolah Ikan Asap } \\
\text { Total (Rp/tahun) } \\
\end{array}$ & $\begin{array}{l}\text { Petani Padi Nonpengolah Ikan Asap } \\
\text { Total (Rp/tahun) } \\
\end{array}$ \\
\hline \multicolumn{3}{|l|}{ Pengeluaran Pangan } \\
\hline Pangan pokok & $3.484 .400,00$ & $3.390 .000,00$ \\
\hline Umbi - umbian & $199.200,00$ & $297.571,43$ \\
\hline Minyak dan lemak & $639.200,00$ & $609.571,43$ \\
\hline Pangan hewani & 1.072 .200 & $1.299 .500,00$ \\
\hline Pangan nabati & $1.016 .800,00$ & $1.530 .142,86$ \\
\hline Buah biji berminyak & $300.000,00$ & $373.428,57$ \\
\hline Kacang - kacangan & $111.200,00$ & $105.142,86$ \\
\hline Gula & $324.800,00$ & $375.857,14$ \\
\hline Sayur berwarna & $547.200,00$ & $688.428,57$ \\
\hline Sayur tak berwarna & $81.600,00$ & $135.928,57$ \\
\hline Sayur buah & $1.732 .600,00$ & $1.814 .285,71$ \\
\hline Buah & $869.600,00$ & $680.857,14$ \\
\hline Minuman & $479.800,00$ & $441.928,57$ \\
\hline Rokok & $2.198 .400,00$ & $2.295 .000,00$ \\
\hline Lainnya & $134.400,00$ & $172.285,71$ \\
\hline Total Pengeluaran Pangan & $13.191 .400,00$ & $14.209 .928,56$ \\
\hline \multicolumn{3}{|l|}{ Pengeluaran Nonpangan } \\
\hline Kesehatan & $300.000,00$ & $285.714,29$ \\
\hline Pendidikan & $1.746 .666,67$ & $1.030 .000,00$ \\
\hline Listrik & $1.199 .200,00$ & $991.142,86$ \\
\hline Telepon/komunikasi & $863.200,00$ & $761.714,29$ \\
\hline Perbaikan rumah & $20.000,00$ & $171.428,57$ \\
\hline Pakaian dan aksesoris & $1.713 .333,33$ & $1.562 .142,86$ \\
\hline Barang dan jasa & $1.200 .000,00$ & 0,00 \\
\hline Bahan bakar & $2.964 .000,00$ & $2.547 .428,57$ \\
\hline Sosial & $2.200 .000,00$ & $2.414 .285,71$ \\
\hline Pajak & $227.333,33$ & $253.102,38$ \\
\hline Kebersihan badan & $984.800,00$ & $1.011 .142,86$ \\
\hline Kosmetik & $495.666,67$ & $267.857,14$ \\
\hline Total Pengeluaran Nonpangan & $13.914 .200,00$ & $11.295 .959,53$ \\
\hline Pengeluaran Rumah Tangga & $27.105 .600,00$ & $25.505 .888,09$ \\
\hline
\end{tabular}


Pengeluaran pangan petani padi sawah di Desa Sukamarga juga menunjukkan bahwa proporsi pengeluaran pangan RT terbesar pertama yaitu pengeluaran untuk kebutuhan pangan pokok, sedangkan proporsi pengeluaran nonpangan terbesar adalah untuk pendidikan anak dan bahan bakar.

Jika dilihat dari kepemilikan luas lahan usahatani padi lebih besar di Desa Sukamarga jika dibandingkan dengan kepemilikan luas lahan di Desa Kebon Damar, Kecamatan Mataram Baru, Kabupaten Lampung Timur. Penelitian yang dilakukan Hernanda et al. (2017) tidak memasukan pengeluaran untuk kebutuhan sosial, perbaikan rumah dan kebersihan badan, sehingga proporsi pengeluaran nonpangan RT di Desa Kebon Damar lebih besar daripada pengeluaran pangan jika dibandingkan dengan proporsi pengeluaran nonpangan di Desa Sukamarga.

\section{Kesejahteraan Rumah Tangga Menurut Kriteria Sajogyo}

Tingkat kesejahteraan RT menurut Sajogyo (1997) dilihat dari besarnya pengeluaran RT per kapita per tahun. Pengeluaran RT per kapita per tahun merupakan pengeluaran total RT, baik dari pengeluaran untuk memenuhi kebutuhan pangan maupun pengeluaran untuk memenuhi kebutuhan nonpangan dibagi dengan jumlah tanggungan RT yang ikut tinggal dalam satu rumah. Total pengeluaran RT kemudian dikonversikan ke dalam ukuran setara dengan harga beras per kilogram menggunakan harga beras yang berlaku di daerah penelitian yaitu Rp9.500,00 per kg.

Hasil dari penelitian ini sejalan dengan hasil penelitian yang dilakukan oleh Khasanah, Murniati dan Widjaya (2018) namun untuk persentase jumlah RT sejahtera di Desa Kebon Damar, Kecamatan Mataram Baru, Kabupaten Lampung Timur lebih besar yaitu berturut-turut sebesar 40 persen dan 28,57 persen. Jika menurut hasil penelitian Khasanah et al. (2018) menunjukkan bahwa terdapat RT petani padi di Kecamatan Sidomulyo dalam keadaan nyaris miskin sebesar 7,40 persen, kategori cukup sebesar 90,74 persen dan kategori hidup layak sebesar 1,85 persen. Keadaan ini dikarenakan sebagian besar RT petani padi ladang di Kecamatan Sidomulyo, Kabupaten Lampung Selatan lebih banyak mengeluarkan belanja RT untuk kebutuhan pangan daripada untuk kebutuhan nonpangan, sedangkan untuk RT petani padi pengolah dan nonpengolah ikan asap cenderung lebih besar mengeluarkan belanja RT untuk kebutuhan nonpangan.

Jumlah sebaran kesejahteraan menurut upah minimum kabupaten (UMK) Lampung Timur dan kesejahteraan kriteria Sajogyo (1997) untuk RT petani padi pengolah ikan asap cenderung sama. Berbeda dengan RT petani padi nonpengolah ikan asap jika dilihat dari kriteria kesejahteraan Sajogyo terdapat tiga RT yang tergolong kedalam kategori nyaris miskin dua diantaranya memiliki pendapatan RT yang tinggi, begitu juga dengan dua puluh tujuh RT dengan kategori hidup cukup ternyata terdapat empat RT yang memiliki tingkat pendapatan rendah dan untuk dua belas RTdengan kategori hidup layak terdapat satu RT dengan tingkat pendapatan rendah. Artinya tidak terlalu banyak perbedaan antara hasil analisis kesejahteraan RT dengan menggunakan teori kesejahteraan kriteria Sajogyo (1997) dan kriteria UMK Kabupaten Lampung Timur. Data tingkat kesejahteraan RT petani padi pengolah dan nonpengolah ikan asap di Desa Kebon Damar, Kecamatan Mataram Baru, Kabupaten Lampung Timur dapat dilihat pada Tabel 3.

Tabel 3. Tingkat kesejahteraan rumah tangga petani padi pengolah dan nonpengolah ikan asap, 2019

\begin{tabular}{lccccc}
\hline \multicolumn{1}{c}{ Golongan } & $\begin{array}{c}\text { Interval skor (setara } \\
\text { beras/tahun) }\end{array}$ & $\begin{array}{c}\text { Jumlah } \\
\text { (jiwa) }\end{array}$ & $\begin{array}{c}\text { Persentase } \\
(\%)\end{array}$ & $\begin{array}{c}\text { Jumlah } \\
\text { (jiwa) }\end{array}$ & $\begin{array}{c}\text { Persentase } \\
(\%)\end{array}$ \\
\hline Paling miskin & $<180 \mathrm{~kg}$ & 0 & 0,00 & 0 & 0,00 \\
Miskin sekali & $181-240 \mathrm{~kg}$ & 0 & 0,00 & 0 & 0,00 \\
Miskin & $241-320 \mathrm{~kg}$ & 1 & 6,67 & 0 & 0,00 \\
Nyaris miskin & $321-480 \mathrm{~kg}$ & 0 & 0,00 & 3 & 7,14 \\
Cukup & $481-960 \mathrm{~kg}$ & 8 & 53,33 & 27 & 64,29 \\
Hidup layak & $>960 \mathrm{~kg}$ & 6 & 40,00 & 12 & 28,57 \\
\hline Jumlah & & 15 & 100,00 & 42 & 100,00 \\
\hline
\end{tabular}




\section{KESIMPULAN}

Kontribusi pendapatan usaha pengolahan ikan asapRT petani padisebesar 54.43 persen dari pendapatan total RT Rp39.314.743,52 per tahun, sedangkan kontribusi pendapatan terbesar RT nonpengolah ikan asap dari usahatani padi sebesar 71,45 persen dari total pendapatan RT sebesar Rp34.749.164,08 per tahun. Rumah tangga pengolahan ikan asap lebih sejahtera dari RT petani padi nonpengolah ikan asap, dikarenakan persentase RT petani padi pengolah ikan asap dalam kategori hidup layak lebih besar yaitu 40,00 persen, sedangkan RT petani padi nonpengolah ikan asap hanya sebesar 28,57 persen.

\section{DAFTAR PUSTAKA}

BPS [Badan Pusat Statistik]. 2018. Berita Resmi Statistik. Badan Pusat Statistik. Jakarta. [13 Desember 2018].

BPS [Badan Pusat Statistik]. 2019. Kabupaten Lampung Timur Dalam Angka: Garis kemiskinan dan penduduk miskin di Kabupaten Lampung Timur, 2012-2018. Badan Pusat Statistik. Lampung Timur.

Khasanah WN, Murniati K, dan Widjaya S. 2018. Pendapatan dan kesejahteraan rumah tangga petani padi ladang di Kecamatan Sidomulyo Kabupaten Lampung Selatan. Jurnal Ilmu Ilmu Agribisnis.5(3):283-291. http://jurnal.fp.unila.ac.id /index.php /JIA/article/view/3064/2439 [15 November 2019].

Hernanda ENP, Indriani $\mathrm{Y}$, dan Kalsum U. Pendapatan dan ketahanan pangan rumah tangga petani padi di desa rawan pangan. Jurnal Ilmu Ilmu Agribisnis. 5(3):283-291. http://jurnal.fp.unila.ac.id /index.php/JIA/article/view/1641/1467 Maret 2019].

Kementerian Pertanian Republik Indonesia. 2019. Data Lima Tahun Terakhir. http://www. pertanian.go.id/home/?show=page \&act=view \&id=61. [16 juni 2019].
Mardliyah, dan Ainul. 2018. Resiko produksi usahatani padi di Kabupaten Lampung Timur. Journal of Food System and Agribusiness. 2(1):8-16. https://jurnal. polinela.ac.id/index. php/JFA/article/view/1106/756. [18 Maret 2019].

Putri CK, Noor TI. 2018. Analisis pendapatan dan tingkat kesejahteraan rumah tangga petani padi sawah berdasarkan luas lahan di Desa Sindangsari, Kecamatan Banjarsari, Kabupaten Ciamis, Provinsi Jawa Barat. Jurnal Ilmiah Mahasiswa Agroinfo Galuh. 4(3):927935.https://jurnal.unigal.ac.id/index. php/agroinfogaluh/article/view/1678 november 2019].

Suparmoko M. 1999. Metode Penelitian Praktis(Untuk Ilmu - Ilmu Sosial, Ekonomi Dan Bisnis) Edisi 4. BPFE-Yogyakarta. Yogyakarta.

Rahim A, dan Hastuti. 2007. Pengantar, Teori, dan Kasus Ekonomika Pertanian. Penebar Swadaya. Depok.

Ramli M, Anggraini, dan Putri Intan. 2012. Nilai tambah pengolahan ikan salai patin (Kasus Di Desa Penyasawan Kecamatan Kampar, Kampar). Berkala Perikanan Terubuk. 4 (2) : 85-95.https://terubuk.ejournal.unri.ac.id/ind ex.php/JT/article/view/1775 [14 Januari 2020]

Sajogyo T. 1997. Garis Kemiskinan dan Kebutuhan Minimum Pangan. LPSB-IPB. Bogor.

Sugesti MT, Abidin Z, dan Kalsum U. 2015. Analisis pendapatan dan pengeluaran rumah tangga petani padi Desa Sukajawa, Kecamatan Bumiratu Nuban, Kabupaten Lampung Tengah. Jurnal Ilmu Ilmu Agribisnis. 3 (3) : 251-259. http://jurnal.fp.unila.ac.id/index.php/JIA/articl e/view/1641/1467 [11 Maret 2020].

Suratiyah K. 2009. Ilmu Usahatani. Penebar Swadaya. Jakarta.

Sugiarto. 2003. Teknik Sampling. Gramedia. Jakarta. 